\title{
Drug safety among institutionalized elderly people: potential interactions $^{a}$
}

\author{
Segurança medicamentosa em idosos institucionalizados: potenciais interações
} Seguridad medicamentosa en ajustes institucionalizados: potencial interacciones

Maria Lígia Silva Nunes Cavalcante ${ }^{1,2}$ (1) Renata Kelly Lopes de Alcântara² Isabelly Costa Lima de Oliveira ${ }^{1}$ Samia Freitas Aires ${ }^{1}$ (1D Ana Lívia Araújo Girão ${ }^{1,3}$ [i] Rhanna Emanuela Fontenele Lima de Carvalho ${ }^{4}$ (iD

${ }^{1}$ Universidade Estadual do Ceará. Fortaleza, CE, Brasil.

${ }^{2}$ Instituição de Longa Permanência Lar Torres de Melo. Fortaleza, CE, Brasil.

${ }^{3}$ Instituto Doutor José Frota. Fortaleza, CE. Brasil.

${ }^{4}$ Universidade Estadual do Ceará, Departamento de Enfermagem. Fortaleza, CE, Brasil.
Corresponding author:

Maria Lígia Silva Nunes Cavalcante.

E-mail:mlsnc14@gmail.com.

Submitted on $02 / 19 / 2019$.

Accepted on 07/30/2019.

DOI: 10.1590/2177-9465-EAN-2019-0042

\begin{abstract}
Objective: to identify the drug interactions among institutionalized elderly. Method: retrospective and documentary study with a quantitative approach developed in two Long Stay Institutions for Elderly, located in northeastern Brazil. Drug interactions were identified by using Drug-Reax ${ }^{\circledR}$ software from the Micromedex database, and they were classified by severity, start time, and documentation. Result: in the 286 analyzed prescriptions, 136 drug interactions were detected in both institutions, most of them classified as severe. The average number of drugs prescribed by the elderly was 4.5 . In the analysis of Pearson's correlation, the number of drug interactions showed a statistically significant correlation with the time of institutionalization and with the amount of drugs administered on the day. Conclusion and implications for practice: the high consumption of drugs and serious drug interactions detected with significant clinical repercussions was evidenced in the study. Knowledge of these interactions is essential for the establishment of preventive safety measures in pharmacotherapy.
\end{abstract}

Keywords: Drug Interactions; Health of the Elderly; Patient Safety.

\section{RESUMO}

Objetivo: Identificar as potenciais interações medicamentosas em idosos institucionalizados. Método: Estudo documental, retrospectivo, com abordagem quantitativa, desenvolvida em duas Instituições de Longa Permanência para Idosos, localizada no nordeste do Brasil. As potenciais interações medicamentosas, do tipo fármaco-fármaco, foram identificadas utilizando o software Drug-Reax $®$ da base de dados Micromedex, e classificadas segundo a gravidade, ao tempo de início e a documentação. Resultados: Nas 286 prescrições, foram detectadas 136 interações medicamentosas nas duas instituições, sendo a maioria classificada como severidade grave. A média de medicamentos prescritos por idosos foi de 4,5. O número de interações medicamentosas apresentou correlação estatisticamente significativa com o tempo de institucionalização e com a quantidade de medicações administradas no dia. Conclusão e implicações para a prática: Foi evidenciado um alto consumo de fármacos e de potenciais interações medicamentosas graves com respostas clínicas significantes. O conhecimento dessas interações é essencial para o estabelecimento de medidas preventivas de segurança na farmacoterapia para essa população.

Palavras-chave: Interações medicamentosas; Saúde do Idoso; Segurança do Paciente.

\section{REsumen}

Objetivo: Identificar las posibles interacciones medicamentosas en ancianos institucionalizados. Metodo: Estudio documental, retrospectivo, con abordaje cuantitativo, desarrollado en dos Instituciones de Larga Permanencia para Ancianos, ubicada en e nordeste de Brasil. Las posibles interacciones medicamentosas, del tipo fármaco-fármaco, fueron identificadas utilizándose e software Drug-Reax $®$ de la base de datos Micromedex, y clasificadas según la gravedad, el tiempo de inicio y la documentación. Resultados: En las 286 prescripciones, se detectaron 136 interacciones medicamentosas en las dos instituciones, siendo la mayoría clasificada como severidad grave. La media de medicamentos prescritos por los ancianos fue 4,5. El número de interacciones medicamentosas presentó correlación estadísticamente significativa con el tiempo de institucionalización y con la cantidad de medicamentos administrados en el día. Conclusión e implicaciones para la práctica: Se evidenció un alto consumo de fármacos y de potenciales interacciones medicamentosas graves con respuestas clínicas significativas. El conocimiento de estas interacciones es esencial para el establecimiento de medidas preventivas de seguridad en la farmacoterapia para esa población.

Palabras clave: Interacciones Medicamentosas; Salud del Anciano; Seguridad del Paciente. 


\section{INTRODUCTION}

The Brazilian demographic transition, resulting from the fecundity and mortality reduction rates, has implied the increase in the number of the elderly over the last years. This ageing process is marked by chronic diseases, such as dyslipidemia, hypertension, diabetes and depression, by passing on the increase in the pharmaceuticals consumption, a condition known as polypharmacy. ${ }^{1}$

That way, the concomitant use of two or more drugs in many cases is necessary, however creates the possibility of interaction between them. Drug interaction is defined as an clinical event whose effects of a drug are affected because of other. ${ }^{2}$ Some drug interactions have a potential to cause harm, and are responsible for the patient's clinical deterioration, prolonged length of stay, while others are mild and do not require special measures. ${ }^{3}$

It is estimated that 35 to $60 \%$ of elderly patients are exposed to potential drug interaction, of which, 5 to $10 \%$ evolve towards serious adverse reaction, that is, harmful and unpleasant reaction, resulting from intervention related to the use of drug. ${ }^{4}$ These adverse reactions may predispose elderly to the occurrence of adverse events, such as falls, fractures, post-surgery confusion, gastrointestinal bleedings, constipation, worsening of congestive heart failure condition, depression, cognitive deficit and renal dysfunction. ${ }^{5}$

A significant proportion of these adverse events may be avoided during the safe drug administration process. The World Health Organization (WHO), in 2002, highlighted the need to reduce avoidable risks and damages to patients, resulting from health care and recommended to all countries that they developed strategies to promote the safe care, bringing as the third international goal the safety in the drug prescription, usage and administration. ${ }^{6}$

In order to meet this proposal, in Brazil it was set up, in 2013, the National Patient Safety Program (NPSP) to contribute with the health care qualification in all establishments of the national territory, aiming to promote risk management and a safe environment. ${ }^{7}$

In institutions which receive elderly people, in order to allow this care occurring in an efficient and safe manner, the different physiological changes resulting from the own senescence process should be considered. Changes such as reduction of the liver and renal function may cause modifications in the pharmacodynamics and pharmacokinetics of several drugs, and can contribute to the occurrence of adverse reactions. ${ }^{8}$

So, before the pharmacological treatment complexity for elderly patients and their vulnerability resulted from the multimorbidity, it is required to provide continuous assessment of the quality of the therapy prescribed for the institutionalized elderly, in order to identify any adverse reactions and/or side effects that affect their quality of life. ${ }^{1}$
However, studies in this area, carried out with the elderly in long stay institutions, are still incipient. ${ }^{9}$ International researches stand out the need to evaluate the severity of drugs interactions and not only the prevalence rate, by emphasizing the limitation of studies carried out with institutionalized elderly, which are more susceptible to use a larger number of drugs, in contrast to extensive researches about potential harms of drugs therapies addressed to hospitalized elderly. ${ }^{10-9,9)}$

In this way, considering the need to prevent and reduce health risks to which elderly living in long stay institutions are exposed, the recognition of drugs interactions and their effects are essential for a more careful pharmacological therapy management, in order to avoid negative clinical outcomes.

In view of the above, the following question has arisen: which are the potential drugs interactions in institutionalized elderly? Therefore, the study aims to identify the potential drugs interactions in institutionalized elderly.

\section{METHOD}

This is a retrospective, documentary study, with quantitative approach, developed in two Long Stay Institutions for Elderly (LSIE), located in the northeast of Brazil.

Institution A is philanthropic and cares for 217 elderly patients, where the clientele range from low, media and high income, prevailing those of low socioeconomic condition.

Institution $B$ has 88 elderly, is maintained with public resources and receive elderly in situation of social vulnerability.

The data were collected during the period of September 2016. All the medical prescriptions, of the last three months, were analyzed by means of a form adapted from a study that determined the prevalence of IM in intensive care units. ${ }^{11}$

The instrument is divided into two parts, the first containing patient's general information (gender, age, date of admission) and the second with information about prescribed drugs, administration time schedules, drugs interactions and clinical effects evaluations. In total, 286 prescriptions were analyzed. It is worth highlighting that these prescriptions are renewed every three months, except when the elderly needs of a medical evaluation due to acute clinical condition.

For identifying potential drugs interactions the Drug-Reax $®$ software from the Micromedex database of Truven Health Analytics was used. The software provides information about the clinical effects or adverse reactions of drugs resulting of interaction, in addition to classify interactions with regard to severity (serious, moderate, mild and contraindicated), time from onset (rapid, slow or unspecified) and the documentation (excellent, good, poor and unknown). ${ }^{12}$ 
With respect to severity, the interactions were classified as serious (when they present life threatening, requiring immediate medical intervention); moderate, (when the patient's clinical condition worsens and there is the need for changing the drug therapy); mild (when the patient present changes in its clinical condition, however, it does not require changes in drug therapy); and contraindicated (when the simultaneous administration is not recommended). ${ }^{12}$ This classification followed the national criteria of potentially inappropriate medication for the elderly (MIP), based on Beers e o Screening Tool of Older Person's Prescriptions (STOPP) criteria. $^{13}$

With respect to the expected time from the start of treatment until arising adverse events (speed of action), the interactions were classified in rapid (when the adverse events occur in less than 24 hours); slow (when the events arise after 24 hours); and unspecified (when the time from onset of adverse events after simultaneous administration of drugs is not documented in the literature). ${ }^{12}$

With regard to documentation, the interactions were classified as excellent (when there are clinical studies that prove the existence of drug interaction); good, (when there is documentation about the interaction, however controlled clinical studies are necessary); moderate (when there are few studies that prove the interaction, however there are pharmacological considerations for occurrence of interaction); poor (when the literature is restricted to case studies); and unknown (when there is no evidence of documentation that prove the drug interaction). ${ }^{12}$

The Micromedex ${ }^{\circledR}$ database is considered as a support tool in medical decision making, in order to prevent the occurrence of adverse effects and promote better clinical practice. Data were complemented with the consulted literature.

Data were organized using the Excel 2010 and the Statistical Package for Social Sciences (SPSS) version 20.0 and analyzed using the Pearson's correlation test (values of $p \leq 0.05$ were considered as significant). For the description of results, tables containing absolute and relative frequencies, means and standard-deviations have been used.

The study was carried out in accordance with the Resolution No. 466 of December 12, 2012 of the National Health Council. The research has been evaluated by the Ethics Committee of the State University of Ceará, obtaining favorable opinion at the date of May 31, 2016, with protocol number 1.574.473.

\section{RESULTS}

Of the 286 analyzed prescriptions, 209 of the Institution $A$ and 77 of the Institution B, 136 (47.5\%) potential drugs interactions were identified, 66 (48.5\%) at the Institution A and 70 (51.4\%) at the Institution B. When analyzing medical prescriptions, 53 (25.4\%) elderly of the institution A and 29 (37.7\%) elderly of the Institution $B$ had at least one interaction.
On the other hand, most elderly who presented drug interaction was male $(51.2 \%)$, with average age of 75 years $( \pm 9)$ at the Institution $A$ and 76 years $( \pm 10)$ at the Institution $B$. No significant correlation has been established between the presence of drug interaction and the gender and age.

With respect to the number of drugs, $96.3 \%$ of elderly of the Institution A and $87.5 \%$ of elderly of the Institution B use at least one drug every day. With regard to number of drugs administered for 24 hours, the average of the Institution A was equivalent to $5( \pm 3)$ and of the Institution B was $4( \pm 2)$. As regards the time of institutionalization of elderly who presented potential drugs interactions, the average was six years for the Institution $A$ and 11 years for the Institution B (Table 1).

In the Pearson's correlation analysis, the number of potential drugs interactions identified presented statistically positive correlation with the institutionalization time $(p=0.04)$ and strong correlation with the quantity of drugs administered/day $(p=0.000)$.

With regard to the classification of the potential drugs interactions identified (Table 2), in general, the severity was classified as serious; the time from onset, when specified, was considered late; and the documentation was poor. With respect to adequate clinical management, at the institution A the patients' symptoms and the laboratory parameters would require monitoring (56.1\%), on the other hand at the Institution $\mathrm{B}$, the more prevalent clinical behavior was the drugs dose adjustment (37.7\%).

In the study 100 different types of drug-drug interactions have been found, however of the 61 types that had highest frequency and that were classified as moderate and serious severity, it should be emphasized the amlodipine + simvastatin interactions $(3.7 \%)$, carbamazepine + quetiapine $(3.7 \%)$, followed by carbamazepine + risperidone (2.9\%) and carvedilol + metformin (2.9\%) (Table 3).

With regard to main clinical effects identified in the serious present drugs interactions are: the cardiotoxicity (change of QT interval), risk of myopathy, the hypoglycemic effect and the increased risk of hemorrhage.

Among the drugs evaluated in the medical prescriptions, the amitriptyline, the benzodiazepines (alprazolam, clonazepam), the chronic use (over 90 days) of hypnotics non benzodiazepines (zolpidem), the furosemide as first-line monotherapy for hypertension and the Spironolactone (higher than $25 \mathrm{mg} /$ day) were considered inappropriate for elderly.

\section{DISCUSSION}

The predominance of women living in both institutions studied, corroborates other findings in the literature. ${ }^{14}$ This predominance is generally justified by the women's greater life expectancy when compared with the men, thereby confirming the phenomenon of feminization of aging. ${ }^{15}$ However, most elderly that presented drug interaction were male (51.2\%), with mean age of 75 years (DP) at the Institution A and 76 years (DP) at the Institution B. 
Table 1. Characterization of elderly who presented potential drugs interactions at the Institution A and B. Brazil, 2016.

\begin{tabular}{|c|c|c|c|c|}
\hline \multirow[b]{2}{*}{ Variables } & \multicolumn{2}{|c|}{ Institution A N (53) } & \multicolumn{2}{|c|}{ Institution B N (29) } \\
\hline & $f$ & $\%$ & $f$ & $\%$ \\
\hline \multicolumn{5}{|l|}{ Gender } \\
\hline Male & 30 & 56.6 & 12 & 41.4 \\
\hline Female & 23 & 43,3 & 17 & 58,6 \\
\hline \multicolumn{5}{|l|}{ Number of elderly with interaction } \\
\hline Yes & 53 & 25.4 & 29 & 37.7 \\
\hline No & 156 & 74.6 & 48 & 62.3 \\
\hline Number of identified interaction * & 66 & - & 70 & - \\
\hline \multicolumn{5}{|c|}{ Number of drugs administered for $24 h^{*}$} \\
\hline $1-5$ & 53 & 100 & 6 & 89.7 \\
\hline $5-10$ & - & - & 2 & 6.9 \\
\hline$>10$ & - & - & 1 & 3.4 \\
\hline \multicolumn{5}{|l|}{ Time of institutionalization* } \\
\hline \multicolumn{5}{|c|}{ Institution A: Average: $6( \pm 6.2)$ Minimum:1; Maximum: 33} \\
\hline \multicolumn{5}{|c|}{ Institution B: Average: 11 ( \pm 9.8$)$ Minimum: 1; Maximum: 41} \\
\hline \multicolumn{5}{|l|}{ Age } \\
\hline \multicolumn{5}{|c|}{ Institution A: Average: 75( \pm 9) Minimum: 60; Maximum: 101} \\
\hline Institution B: Average: $76( \pm 10) \mathrm{Mi}$ & laxim & & & \\
\hline
\end{tabular}

Source: Research data, 2016.

Note: ${ }^{*} p<0.05$

Table 2. Classification of the potential drugs interactions identified at the Institution A and B. Brazil, 2016.

\begin{tabular}{|c|c|c|c|c|}
\hline \multirow[b]{2}{*}{ Variables } & \multicolumn{2}{|c|}{ Institution A } & \multicolumn{2}{|c|}{ Institution B } \\
\hline & $f$ & $\%$ & $f$ & $\%$ \\
\hline \multicolumn{5}{|l|}{ Severity } \\
\hline Serious & 45 & 68.2 & 47 & 67.1 \\
\hline Moderate & 20 & 30.3 & 22 & 31.5 \\
\hline Mild & 1 & 1.5 & 1 & 1.5 \\
\hline \multicolumn{5}{|l|}{ Time from onset } \\
\hline Immediate & 11 & 16.7 & 7 & 10.0 \\
\hline Late & 17 & 25.8 & 23 & 32.9 \\
\hline Unspecified & 38 & 57.6 & 40 & 57.1 \\
\hline \multicolumn{5}{|l|}{ Documentation } \\
\hline Poor & 33 & 50,0 & 34 & 48,6 \\
\hline Good & 26 & 39.4 & 33 & 47.1 \\
\hline Excellent & 7 & 10.6 & 3 & 4.3 \\
\hline \multicolumn{5}{|l|}{ Clinical Management } \\
\hline Monitor clinical symptoms and laboratory parameters & 37 & 56.1 & 16 & 22.9 \\
\hline The physician should adjust the dose & 18 & 27.3 & 26 & 37.7 \\
\hline The physician should replace with another drug & 9 & 13,6 & 25 & 35,7 \\
\hline The nurse should modify the time schedule & 2 & 3,0 & 1 & 1,5 \\
\hline Unspecified & - & - & 2 & 2,9 \\
\hline
\end{tabular}

Souce: Research data, 2016. 
Table 3. Description of drug interactions according to clinical effect, severity and frequency, met in LSIE. Brazil, 2016.

\begin{tabular}{|c|c|c|c|c|}
\hline \multicolumn{2}{|c|}{ Drug - drug interaction } & \multirow{2}{*}{$\begin{array}{l}\text { Clinical Effect } \\
\text { Results in increase of the Simvastatin exposure and increased risk of } \\
\text { myopathy, including rhabdomyolysis. }\end{array}$} & \multirow{2}{*}{$\begin{array}{l}\text { Severity } \\
\text { Serious }\end{array}$} & \multirow{2}{*}{$f(\%)$} \\
\hline Amlodipine & Simvastatin & & & \\
\hline \multirow[t]{2}{*}{ Carbamazepine } & Quetiapine & $\begin{array}{l}\text { Increased exposure of Carbamazepine and the reduced risk of } \\
\text { toxicity and effectiveness with Quetiapine. Ataxia, nausea, twitching } \\
\text { and diplopia. }\end{array}$ & Serious & $5(3.7)$ \\
\hline & Risperidone & Increased clearance of the Risperidone, loss of treatment efficacy. & Moderate & $4(2.9)$ \\
\hline Carvedilol & Metformin & $\begin{array}{l}\text { It may result in hypoglycemia or hyperglycemia; reduction of } \\
\text { hypoglycemia symptoms. }\end{array}$ & Moderate & $4(2.9)$ \\
\hline AAS & Metformin & $\begin{array}{l}\text { The hypoglycemiant effect may increase with moderate doses of } \\
\text { ASA }\end{array}$ & Serious & $3(2.2)$ \\
\hline Citalopram & Risperidone & $\begin{array}{l}\text { Additive effects on the QT interval. They may result in increased risk } \\
\text { of severe cardiac events. }\end{array}$ & Serious & $3(2.2)$ \\
\hline Hydroxyzin & Quetiapine & $\begin{array}{l}\text { Additive effects on the QT interval. They may result in increased risk } \\
\text { of severe cardiac events. }\end{array}$ & Serious & $3(2.2)$ \\
\hline \multirow{2}{*}{ Quetiapine } & Risperidone & $\begin{array}{l}\text { Additive effects on the QT interval. They may result in increased risk } \\
\text { severe cardiac events. }\end{array}$ & Serious & $3(2.2)$ \\
\hline & Trazodone & $\begin{array}{l}\text { Additive effects on the QT interval. They may result in increased risk } \\
\text { of severe cardiac events. }\end{array}$ & Serious & $3(2.2)$ \\
\hline AAS & Valproic Acid & Increased plasmatic concentration of Valproic Acid. & Serious & $2(1.5)$ \\
\hline Valproic Acid & Risperidone & Increase of the plasmatic concentration of Valproic Acid. & Serious & 2(1.5) \\
\hline Atenolol & Metformin & $\begin{array}{l}\text { The concomitant use of antidiabetic agents and beta-blockers } \\
\text { can result in hypoglycemia or hyperglycemia; Reduction of } \\
\text { hypoglycemia symptoms }\end{array}$ & Moderate & $2(1.5)$ \\
\hline \multirow{3}{*}{ Carbamazepine } & Phenobarbital & Reduced Carbamazepine efficiency. & Moderate & $2(1.5)$ \\
\hline & Haloperidol & Reduced plasma concentration of Haloperidol. & Moderate & $2(1.5)$ \\
\hline & Zolpidem & Increased clearance of Zolpidem. & Serious & 2(1.5) \\
\hline \multirow{3}{*}{ Carbolithium } & Phenergan & $\begin{array}{l}\text { The concomitant use causes weakness, dyskinesia, increased } \\
\text { extrapyramidal symptoms, encephalopathy and brain damages. }\end{array}$ & Serious & 2(1.5) \\
\hline & Neozine & $\begin{array}{l}\text { Weakness, dyskinesia, increased extrapyramidal symptoms, } \\
\text { encephalopathy, and brain damages. }\end{array}$ & Serious & $2(1.5)$ \\
\hline & Haldol & $\begin{array}{l}\text { The concomitant use causes weakness, dyskinesia, increased } \\
\text { extrapyramidal symptoms, encephalopathy and brain damages. }\end{array}$ & Serious & $2(1.5)$ \\
\hline Chlorpromazine & Quetiapine & $\begin{array}{l}\text { Additive effects on the QT interval. They can result in increased risk } \\
\text { of serious cardiac events. }\end{array}$ & Serious & $2(1.5)$ \\
\hline Digoxin & Furosemide & $\begin{array}{l}\text { Result in toxicity of the digoxin (nauseas and vomiting, cardiac } \\
\text { arrythmias). }\end{array}$ & Moderate & $2(1.5)$ \\
\hline \multirow{2}{*}{ Escitalopram } & Haldol & $\begin{array}{l}\text { Additive effects on the QT interval. They can result in increased risk } \\
\text { of serious cardiac events. }\end{array}$ & Serious & $2(1.5)$ \\
\hline & Risperidone & $\begin{array}{l}\text { Additive effects on the QT interval. They can result in increased risk } \\
\text { of serious cardiac events. }\end{array}$ & Serious & $2(1.5)$ \\
\hline HCTZ & Enalapril & Reduction on blood pressure & Moderate & $2(1.5)$ \\
\hline
\end{tabular}

Source: Research data, 2016. 
The minimum residence time of the elderly at the institutions was one year and the maximum was 41 years. The institutionalization time of the elderly presented statistically significant correlation with the number of drugs interactions identified in the study $(p=0.04)$. Such fact may be justified by the greater vulnerability of institutionalized elderly to present limiting diseases, weaknesses, low functionality, being these, the main factors associated with polypharmacy and, as a result, the increased probability of drug interactions and/or adverse reactions. ${ }^{16}$

Regarding mean age found in the study, $75 \pm 9$ at the Institution $A$ and $76 \pm 10$ years at the Institution $B$, are similar to other Brazilian researches, that point to the increase of long-lived elderly profile. ${ }^{17,14}$ The elderly into age group above 80 years, called "older" or "elderly in advanced age", constitute the fastest growing population segment in recent times, this fact is justified by the gain on the mortality and, as a result, the increased life expectancy. ${ }^{1}$

Concomitant with these demographic changes in the country, there were changes in the population's morbimortality behavior, thus, changing the Brazilian epidemiological profile, which became marked by chronic diseases such as disabilities and weaknesses, which require continuous and specialized health system interventions. ${ }^{18}$

As a result of the predominance of chronic-degenerative diseases, the elderly population uses several drugs, triggering the polypharmacy. ${ }^{19}$ It must be stressed that $96.3 \%$ of the elderly of Institution A use at least one drug once a day. Similar findings were observed in a LSIE of the South of Brazil, which stood out the only $3 \%$ of the elderly did not use medications.$^{17}$

The study identified that the average amount of drugs prescribed for the elderly in the two studied LSIE was 4.5 drugs/ elderly. The number of potential drugs interactions identified showed strong correlation with the amount of drugs administered on the day $(p=0.000)$. The number of drugs obtained is high when compared with a study carried out in the South region of Brazil, that had an average of 3.7 drugs/elderly and lower when compared with the results found in a LSIE of the Southeast region, which obtained an average of 7 drugs used by elderly. ${ }^{19-20}$ When comparing data of Brazilian studies with an international study, the average is considered low. Study conducted in Finland identified an average of 8 drugs regularly administered to each elderly. ${ }^{10}$

The simultaneous use of drugs is prevalent in the elderly population and a constant concern in the LSIE over the last decades. Several negative consequences are associated with the consumption of multiple drugs, such as: the increase in health care costs; the increase of the risk of adverse events and drugs interactions; the decreased adherence to drug; the functional capacity reduction; and multiple geriatric syndromes. ${ }^{21}$
A the end of the study prescriptions analysis, $25.4 \%$ of elderly of the Institution A and $37.7 \%$ of elderly of the institution $B$ showed, at least, one drug interaction, in which most were classified as serious severity. Unlike what occurred in the South of Brazil, a research identified a greater number of drugs interactions, $39.8 \%$ of the prescriptions analyzed, on the other hand, $64.9 \%$ of these were of moderate severity. ${ }^{22}$

In addition to the consumption of multiple drugs, another factor also contributing to the occurrence of drugs interactions is the distribution of drugs at standardized time schedules, which enables administering several drugs at the same time. ${ }^{16}$

The safe time schedule is the responsibility of the nurse and many times follows a pre-established time schedule. However, it requires attention to the adequate planning of the drugs and their intervals, preventing possible drugs interactions and damages to patients. ${ }^{23}$

It is worth highlighting that in the study 100 different types of drug-drug interactions were found, of which 61 types of drugs interactions that showed greatest frequency in the two institutions studied. One of the serious more prevalent drugs interactions was the association of the drugs amlodipine and simvastatin, observed in $5(3.7 \%)$ medical prescriptions. Similar result was found in the Brazilian southeast, through a study carried out with hypertensive elderly attended in a Basic Health Unit. ${ }^{24}$

The amlodipine and the simvastatin, when administered jointly, show a serious drug interaction, resulting in prolonged exposure of the simvastatin and risk of myopathy, including the rhabdomyolysis. ${ }^{12}$ Another frequent drug interaction in the study was the simultaneous use of the Carbamazepine with the risperidone. Study conducted in Finland also identified the same interaction as one of the most frequent in institutionalized elderly. ${ }^{10}$ This interaction causes increased clearance of the risperidone, which results in the loss of its effectiveness. ${ }^{12}$

The choice of the drug therapy in the elderly is regarded as a challenge, because of the potential development of side effects and drugs interactions, occasioned by the chronic use of drugs and polypharmacy. ${ }^{8}$ Moreover, with the physiological alterations of the ageing, a change in the drugs pharmacokinetics and pharmacodynamics could contribute to the negative clinical effects. ${ }^{8}$

The more identified clinical implications of the serious drugs interactions were the cardiotoxicity (change on the QT interval), the risk of myopathy, the hypoglycemiant effect and the increased risk of hemorrhage. Study conducted, in the Southeast of Brazil, with the elderly of the community corroborate the findings of this research. ${ }^{24}$ These outcomes may influence the functionality and the quality of life of the elderly, thus, it is needed the monitoring of the clinical symptoms, the laboratory parameters and the dose adjustment. ${ }^{24}$ 
Besides concerns for the drugs interactions, some drugs are considered as potentially inadequate for the elderly, among them, the benzodiazepines prescription, which generally increase the risk of cognitive impairment, delirium, falls and fractures. Following prescription these drugs, monitoring these patients and the knowledge of risks associated to these drugs use is essential for helping to detect adverse effects, or to avoid that these are mistaken for new diseases. ${ }^{9}$

Given the pharmacotherapy complexity of the elderly, the balance between the risks and benefits is essential for the safe and rational use of drugs. ${ }^{1}$ The clinical judgement is fundamental for establishing an adequate prescription, and should take into account the uniqueness of each patient and objectives of the treatment. ${ }^{13}$

Within this context, the nursing practice is essential to establish a safe therapeutic plan for the institutionalized elderly, aiming at its well-being, its autonomy, its quality of life and the improvement in its health condition. To this end, the nursing team needs further pharmacological deepening to identify possible drugs interactions and practicing strategies for patient monitoring.

\section{CONCLUSIONS AND IMPLICATIONS FOR PRACTICE}

The high consumption of drugs was shown in the two studied LSIE, with the occurrence of 100 different types of drug-drug interactions, besides the high prevalence of drugs interactions evaluated as serious and with significant clinical repercussions.

From our findings, the study contributed to the knowledge of the main drugs interactions in the institutionalized elderly, and has become an essential tool to establish preventive safety measures in pharmacotherapy, contributing for an efficient and quality healthcare for the elderly.

The research stands out as the limitation the method used for data collection. The use of the software provides only the potential drugs interactions, what does not mean that the adverse events manifest clinically in all the patients. Another limiting factor is that the drugs dosages and the time of treatment were not observed, thus, an overestimated value of interactions may occur.

It should be pointed out the importance of carrying out more in-depth analysis of drugs interactions and clinical effects found in the research with new intervening variables, such as the comorbidities and degree of dependence of the elderly, for implementation of other correlations tests.

\section{REFERENCES}

1. Rodrigues MCS, Oliveira C. Drug-drug interactions and adverse drug reactions in polypharmacy among older adults: an integrative review. Rev Latino-Am Enfermagem. [Internet]. 2016; [cited 2018 jul 26] $24: e 2800$. Available from: http://www.scielo.br/scielo.php?script=sci arttext\&pid=S0104-11692016000100613\&Ing=en\&nrm=iso\&tlng=en DOI: http://doi.org/10.1590/1518-8345.1316.2800
2. Moreira MB, Mesquita MGR, Stipp MAC, Paes GO. Potential intravenous drug interactions in intensive care. Rev Esc Enferm USP [Internet]. 2017; [cited 2019 jun 15]; 51:e03233. Available from: https://www.revistas.usp. br/reeusp/article/view/134927/130691 DOI: https://doi.org/10.1590/ S1980-220X2016034803233

3. Tatro DS. Drug Interaction Facts: the authority on drug interactions. St. Louis: Facts \& Comparisons; 1999.

4. Magro L, Moretti U, Leone R. Epidemiology and characteristics of adverse drug reactions caused by drug-drug interactions. Expert Opin Drug Saf [Internet]. 2012 jan; [cited 2018 jul 26]; 11(1):83-94. Available from: https://www.ncbi.nlm.nih.gov/pubmed/22022824 DOI: https://doi. org/10.1517/14740338.2012.631910

5. Muhlack DC, Hoppe LK, Weberpals J, Brenner H, Schöttker B. The Association of Potentially Inappropriate Medication at Older Age with Cardiovascular Events and Overall Mortality: A Systematic Review and Meta-Analysis. J Am Med Dir Assoc [Internet]. 2017 mar; [cited 2018 jul 25]; 18(3):211-220. Available from: https://www.jamda.com/ article/S1525-8610(16)30557-6/fulltext DOI: https://doi.org/10.1016/j. jamda.2016.11.025

6. World Health Organization (WHO). Conceptual Framework for the International Classification for Patient Safety. Final Technical Report - Jan 2009. Geneva: WHO [Internet]. 2009 jan; [cited 2018 aug 30]. Available from: http://www.who.int/patientsafety/taxonomy/icps_full_report.pdf

7. Ministério da Saúde (BR). Agência Nacional de Vigilância Sanitária. Resolução - RDC no 36, de 25 de julho de 2013. Institui ações para a segurança do paciente em serviços de saúde e dá outras providências. Brasília (DF): Ministério da Saúde [Internet]. 2013; [cited 2018 aug 30]. Available from: http://bvsms.saude.gov.br/bvs/saudelegis/anvisa/2013/ rdc0036 25_07_2013.html

8. Vrdoljak D, Borovac JA. Medication in the elderly - considerations and therapy prescription guidelines. Acta Med Acad [Internet]. 2015; [cited 2018 jul 25]; 44(2):159-68. Available from: https://www.ncbi.nlm.nih.gov/ pubmed/26702910 DOI: https://doi.org/10.5644/ama2006-124.142

9. Storms H, Marquet K, Aertgeerts B, Claes N. Prevalence of inappropriate medication use in residential long-term care facilities for the elderly: A systematic review. Eur J Gen Pract [Internet]. 2017 mar; [cited 2018 jul 25]; 23(1):69-77. Available from: http://dx.doi.org/10.1080/13814788.2 017.1288211

10. Teramura-Gronblad M, Raivio M, Savikko N, Muurinen S, Soini H, Suominen $\mathrm{M}$, et al. Potentially severe drug-drug interactions among older people and associations in assisted living facilities in Finland: a cross-sectional study. Scand J Prim Health Care [Internet]. $2016 \mathrm{sep}$ [cited 2018 jul 25]; 34(3):250-57. Available from: https://www.ncbi.nlm nih.gov/pmc/articles/PMC5036014/ DOI: https://doi.org/10.1080/0281 3432.2016.1207142

11. Carvalho REFL, Reis AMM, Faria LMP, Zago KSA, Cassiani SHBC. Prevalence of drug interactions in intensive care units in Brazil. Acta Paul Enferm [Internet]. 2013; [cited 2018 aug 30]; 26(2):150-7. Available from: http://www.scielo.br/scielo.php?script=sci_arttext\&pid =S0103-21002013000200008 DOI: http://dx.doi.org/10.1590/S010321002013000200008

12. Micromedex Healthcare Series. Truven Health Analytics [Internet] Connecticut; 2016; [cited 2018 jul 25]. Available from: https://rdl.lib. uconn.edu/byTitle.php

13. Oliveira MG, Amorim WW, Oliveira CRB, Coqueiro HL, Gusmão LC, Passos LC. Brazilian consensus of potentially inappropriate medication for elderly people. Geriatr Gerontol Aging [Internet]. 2016; [cited 2018 ju 25]; 10(4):168-181. Available from: http://www.ggaging.com/details/397/ en-US/brazilian-consensus-of-potentially-inappropriate-medication-forelderly-people DOI: https://doi.org/10.5327/Z2447-211520161600054

14. Güths JFS, et al. Perfil sociodemográfico, aspectos familiares, percepção de saúde, capacidade funcional e depressão em idosos institucionalizados no Litoral Norte do Rio Grande do Sul, Brasil. Rev Bras Geriatr Gerontol [Internet]. 2017 apr; [cited 2018 jul 04]; 20(2): 175-185. Available from: http://www.scielo.br/scielo.php?script=sci arttext\&pid=S1809-98232017000200175\&lng=en DOI: http://dx.doi. org/10.1590/1981-22562017020.160058 
15. Almeida AV, Mafra SCT, Silva EP, Kanso S. The Feminization of Old Age: a focus on the socioeconomic, personal and family characteristics of the elderly and the social risk. Textos \& Contextos [Internet]. 2015 jan/jun; [cited 2018 jul 25]; 14(1):115-31. Available from: http:// revistaseletronicas.pucrs.br/ojs/index.php/fass/article/view/19830 DOI: http://dx.doi.org/10.15448/1677-9509.2015.1.19830

16. Borges CL, Silva MJ, Clares JWB, Nogueira JM, Freitas MC. Sociodemographic and clinical characteristics of institutionalized older adults: contributions to nursing care. Rev Enferm UERJ [Internet]. 2015; [cited 2018 jul 25]; 23(3):381-7. Available from http://www.e-publicacoes.uerj.br/index.php/enfermagemuerj/article/ view/4214/18305 DOI: http://dx.doi.org/10.12957/reuerj.2015.4214

17. Smanioto FN, Haddad MCL. Evaluation of pharmacotherapy prescribed to institutionalized elderly. Rev Bras Enferm [Internet]. 2013 aug; [cited 2018 jul 25]; 66(4):523-27. Available from: http://www.scielo.br/scielo. php?script=sci_arttext\&pid=S0034-71672013000400009. DOI: http:// dx.doi.org/10.1590/S0034-71672013000400009

18. Miranda GMD, Mendes ACG, Silva ALA. Population aging in Brazil: current and future social challenges and consequences. Rev Bras Geriatr Gerontol [Internet].2016 jun; [cited 2019 jun 12]; 19(3):507-19. Available from: http:// www.scielo.br/pdf/rbgg/v19n3/pt_1809-9823-rbgg-19-03-00507.pdf DOI: https://doi.org/10.1590/1809-98232016019.150140

19. Gautério-Abreu DP, Santos SSC, Ilha S, Roggia PD. Improper use of drugs in elderly residents in a long stay institution. Rev Enferm UFPE On line [Internet]. 2016 feb; [cited 2019 jun 12]; 10(2):608-14. Available from: https://periodicos.ufpe.br/revistas/revistaenfermagem/article/ download/10996/12353 DOI: https://doi.org/10.5205/reuol.855774661-1-SM1002201630
20. Assis DL, Chagas VO, Valente M, Gorzoni ML. Polypharmacy and the use of inappropriate medications in institutionalized elderly: lessons still not learned. Geriatr Gerontol Aging [Internet]. 2016; [cited 2019 jun 12]; 10(3):126-31. Available from: http://ggaging.com/details/376/ en-US/polifarmacia-e-uso-de-medicamentos-inapropriados-emidosos-institucionalizados--licoes-ainda-nao-aprendidas

21. Maher RL, Hanlon J, Hajjar ER. Clinical consequences of polypharmacy in elderly. Expert Opin Drug Saf [Internet]. 2014 jan; [cited 2018 jul 25] 13(1):57-65. Available from: https://www.ncbi.nlm.nih.gov/pmc/articles/ PMC3864987/ DOI: https://doi.org/10.1517/14740338.2013.827660

22. Gerlack LF, Cuentro VS, Estrela MFB, Karnikowski MGO, Pinho DLM, Bós AJG. Interações medicamentosas na farmacoterapia prescrita a idosos residentes em uma instituição de longa permanência brasileira. Estud Interdiscipl Envelhec [Internet]. 2014; [cited 2019 jun 12] 19(2):439-52. Available from: http://www.seer.ufrgs.br/RevEnvelhecer/ article/view/43273

23. Antunes JFS, Okuno MFP, Lopes MCBT, Campanharo CRV, Batista REA. Drug interaction in elderly inpatients in the emergency department of a university hospital. REME Rev Min Enferm [Internet]. 2015 oct/ dec; [cited 2019 jun 12]; 19(4):907-912. Available from: http://www. reme.org.br/artigo/detalhes/1059 DOI: https://doi.org/10.5935/14152762.20150070

24. Pinto NBF, Vieira LB, Pereira FMV, Reis AMM, Cassiani SHDB Drug interactions in prescriptions for elderly hypertensive patients: prevalence and clinical significance. Rev Enferm UERJ [Internet]. $2014 \mathrm{nov} / \mathrm{dec}$; [cited 2018 jul 25]; 22(6):735-41. Available from: http://www.e-publicacoes.uerj.br/index.php/enfermagemuerj/article/ view/7111 DOI: https://doi.org/10.12957/reuerj.2014.7111

\footnotetext{
a Article extracted from the Master dissertation "Safety in the drug administration process to elderly persons living in Long Stay Institution”. Author: Maria Lígia
} Silva Nunes Cavalcante. Orientadora: Rhanna Emanuela Fontenele Lima de Carvalho. 